\title{
Establishment and metabolic analysis of a model microbial community for understanding trophic and electron accepting interactions of subsurface anaerobic environments
}

\author{
Lance D Miller1,2, Jennifer J Mosher1,2, Amudhan Venkateswaran1,2, Zamin K Yang 1,2, Anthony V Palumbo 1,2, \\ Tommy J Phelps 1,2, Mircea Podar1,2, Christopher W Schadt1,2 and Martin Keller*1,2
}

\begin{abstract}
Background: Communities of microorganisms control the rates of key biogeochemical cycles, and are important for biotechnology, bioremediation, and industrial microbiological processes. For this reason, we constructed a model microbial community comprised of three species dependent on trophic interactions. The three species microbial community was comprised of Clostridium cellulolyticum, Desulfovibrio vulgaris Hildenborough, and Geobacter sulfurreducens and was grown under continuous culture conditions. Cellobiose served as the carbon and energy source for C. cellulolyticum, whereas D. vulgaris and G. sulfurreducens derived carbon and energy from the metabolic products of cellobiose fermentation and were provided with sulfate and fumarate respectively as electron acceptors.

Results: qPCR monitoring of the culture revealed C. cellulolyticum to be dominant as expected and confirmed the presence of D. vulgaris and G. sulfurreducens. Proposed metabolic modeling of carbon and electron flow of the threespecies community indicated that the growth of C. cellulolyticum and D. vulgaris were electron donor limited whereas G. sulfurreducens was electron acceptor limited.

Conclusions: The results demonstrate that C. cellulolyticum, D. vulgaris, and G. sulfurreducens can be grown in coculture in a continuous culture system in which D. vulgaris and G. sulfurreducens are dependent upon the metabolic byproducts of $C$. cellulolyticum for nutrients. This represents a step towards developing a tractable model ecosystem comprised of members representing the functional groups of a trophic network.
\end{abstract}

\section{Background}

Cultivation of individual microbial species has been at the core of experimental microbiology for more than a century but offers only a glimpse into the collective metabolism, ecology and ecophysiological potential of natural microbial systems. Microbial communities rather than individual species generally control process rates and drive key biogeochemical cycles, including those that determine the transformation of environmental pollutants. While the relatively recent advances in molecular ecology and metagenomic-enabled studies of microbial communities have greatly advanced our understanding of

* Correspondence: kellerm@ornl.gov

1 Biosciences and Environmental Sciences Division, Oak Ridge National Laboratory, Oak Ridge, TN 37831, USA

Full list of author information is available at the end of the article natural and engineered systems, such systems are often not amenable to precise experimental manipulation. Controlled studies of model consortia comprised of multiple species that mediate important biological processes are essential for advancing our understanding of many diverse areas of microbial ecology. Model consortia studies may be especially pertinent to engineered and biotechnology relevant processes including; human and animal environments [1-3], processes relevant to bioremediation and natural attenuation [4-6], bacterially mediated wastewater treatment processes $[7,8]$, and industrial biotechnological applications [9].

In their natural environments, microbial communities are often growth-limited by the availability of carbon and energy [10-12]. For this reason, growth of bacteria in car- 
bon limited continuous-culture systems more closely resembles that in natural ecosystems [13] in contrast to the excess nutrients provided in most microbiological media [13]. Moreover, the steady-state growth condition afforded by continuous-culture systems is more precise and statistically reproducible than the constantly changing physiological states of cells grown under batch culture conditions $[13,14]$. Therefore these approaches may be favored for model community studies.

Previous studies of mixed cultures in the laboratory focused on understanding the syntrophic growth of sulfate-reducers and methanogens $[15,16]$, competition for nutrients and electron sinks between microorganisms [17-20], and functional community stability [21-23]. However, there is a lack of studies on consortia of microorganisms representing the higher-level trophic interactions based on the archetypical models of the functional groups within a trophic network. For example, an ideal model consortium representing a subsurface anoxic community might comprise a group of microorganisms representing several oxidation-reduction levels. This community would be capable of extracting considerable energy from organic monomers or polymers through various trophic interactions and several terminal electronacceptor processes, ending with the least thermodynamically favorable process of methanogenesis. In undisturbed and unstimulated groundwater systems the primary carbon sources available may include humic acids and complex mixtures of carbohydrates that derive from the breakdown of vegetation inputs and cell wall constituents, as well as volatile fatty acids derived from the microbial breakdown of such inputs [24,25]. Microbial activity in these systems is thought to be primarily driven by fermenters of complex carbohydrates, with subsequent utilization of fermentation products such as acetate, ethanol and other volatile fatty acids by sulfate reducing bacteria $(\mathrm{SRB})$ and ferric iron reducing bacteria (FRB) that oxidize these products [26-30].

As a first step towards developing a model anaerobic and syntrophic community, we sought to use 3 to 4 model organisms to serve as archetypes for the various functional redox groups. All candidate microorganisms have sequenced genomes http://genome.jgi-psf.org/cloce/ cloce.info.html[31,32], tractable genetic systems [33-36], and have been previously studied individually or in coculture in continuous flow systems [37-42]. Clostridium cellulolyticum was chosen as the basal organism due the diverse ability of this organism for the fermentation of complex carbohydrate polymers. As it ferments cellobiose, for example, acetate, lactate, ethanol and hydrogen are produced that can potentially be used by other organisms including SRB and FRB. The secondary stage in the chain of nutrient and electron flow was represented by both Desulfovibrio vulgaris and by Geobacter sulfurre- ducens, each of which can utilize the metabolites of $C$. cellulolyticum. In this system, D. vulgaris and G. sulfurreducens were provided with sulfate and fumarate, respectively, as electron-acceptors in order to avoid electronacceptor competition as well as the precipitates from using ferric iron as an electron-acceptor for Geobacter. Both Desulfovibrio-like and Geobacter-like organisms also represent organisms commonly responsible for the reduction of Uranium, Chromium and other heavy metals as found in contaminated sites [27-30,43,44]. By constructing this consortia from the a priori criteria described above, we were also able to quickly refine minimal medium and cultivation conditions. This strategy also enables the future development and application of analytical methods that take full advantage of genome enabled tools to characterize and track consortia dynamics at the molecular level.

The goals of this study were to; 1) develop a stable microbial consortia in continuous flow systems that could be used for physiological and functional genomic studies in tractable and manipulable experiments, 2) to develop and apply analytical methods for quantifying the community members and monitoring individual as well as community metabolism, and 3) to build a simple metabolic model of the community. Here we present analysis of a stable consortium comprised of C. cellulolyticum, $D$. vulgaris, and G. sulfurreducens for understanding trophic interactions in anaerobic subsurface environments.

\section{Results and Discussion}

\section{Tri-culture inoculation and metabolite monitoring reveals} limiting nutrients

Two custom built continuous culture vessels as described in the Materials and Methods section and shown in Figure 1 were each inoculated with $50 \mathrm{ml}$ of a previously grown three species community culture comprised of $C$. cellulolyticum, D. vulgaris, and G. sulfurreducens with cell numbers and ratios similar to those described here as determined by qPCR that was grown under the same continuous flow conditions. In order to determine the basic metabolic interactions between the three species within this community as it reached steady state, the vessels and the metabolites were monitored. Samples were collected daily from the bioreactor outflow. The $\mathrm{OD}_{600}$ of the culture peaked on day 4 at $\sim 0.5$ before stabilizing at $0.4 \pm 0.03$ (Figure 2). The $\mathrm{pH}$ remained stable between 7.0 and 7.2 for the course of the experiment without the need for $\mathrm{pH}$ control (data not shown). Samples $(10 \mathrm{ml})$ were stored at $-20^{\circ} \mathrm{C}$ for subsequent qPCR analysis, while identical samples $(0.5-1 \mathrm{ml})$ were stored at $-20^{\circ} \mathrm{C}$ for subsequent GC/MS and or HPLC metabolite analysis. The results, shown in Figure 2, were similar to that achieved by a second replicate co-culture grown simultaneously, as 


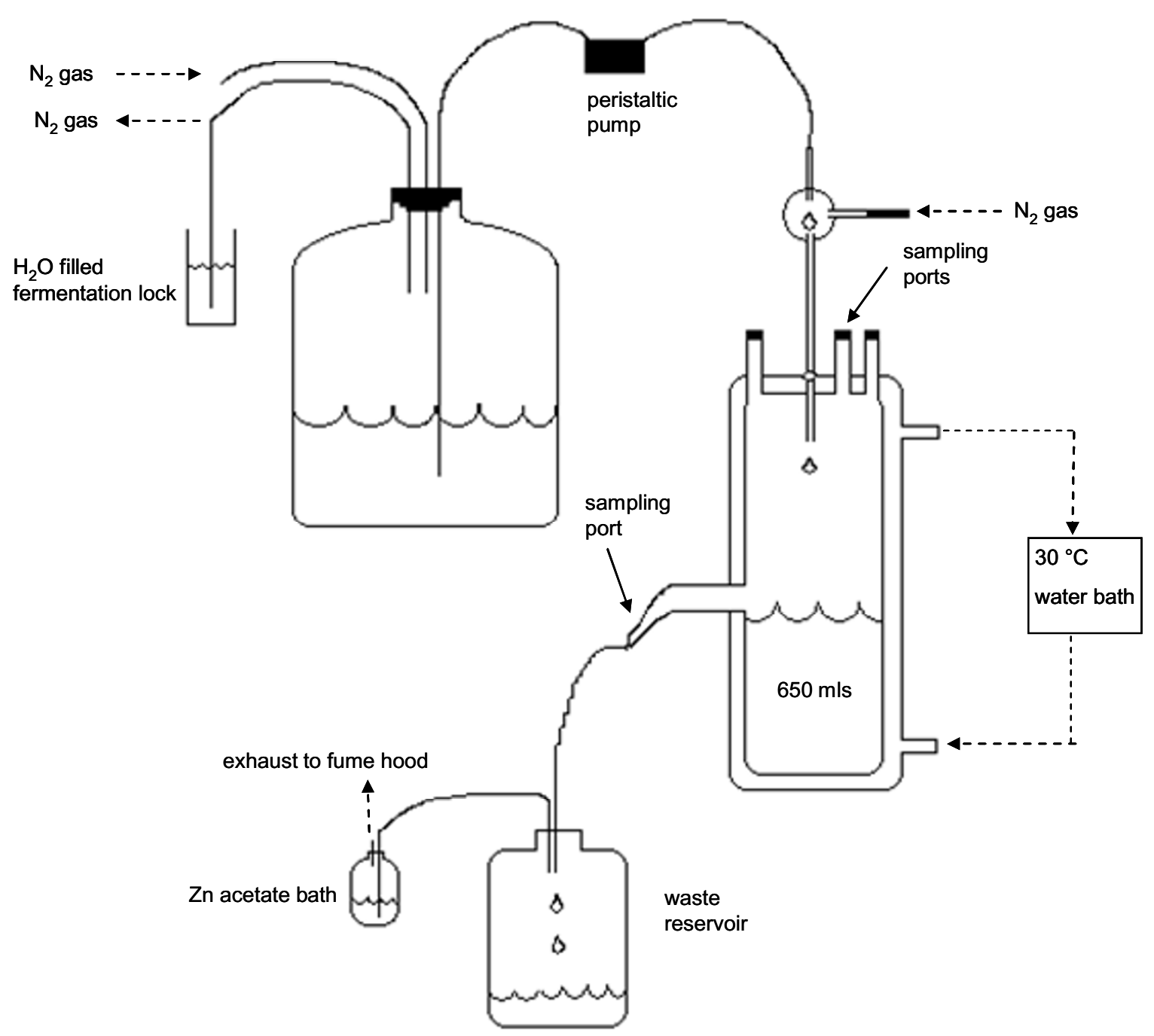

Figure 1 Chemostat setup. Schematic diagram illustrating the experimental setup. See text for details.

well as to six other continuous culture experiments conducted over a 12 month period (data not shown).

In all co-cultures, the $2.2 \mathrm{mM}$ cellobiose decreased to less than $0.5 \mathrm{mM}$ within 2 days and thereafter rarely exceeded $0.1 \mathrm{mM}$ (Figure 2 and Additional File 1). This was different than in preliminary continuous culture experiments where non-steady state "upsets" occurred that were often associated with sporulation of $\mathrm{C}$. cellulolyticum. In these cases, the concentration of cellobiose reached up to $2 \mathrm{mM}$ for three or more days until a new steady state approached. Cellobiose fermentation resulted primarily in the production of acetate and $\mathrm{CO}_{2}$ at steady state. While quantifiable $\mathrm{CO}_{2}$ was within the nitrogen gas flushed across the vessel headspace and exiting the vessel, hydrogen remained below the $0.3 \mu \mathrm{M}$ detection limit. The concentrations of these compounds stabilized as the culture reached a stable optical density of
0.4. Ethanol was also occasionally detected at trace amounts.

D. vulgaris likely utilized $\mathrm{H}_{2}$ and ethanol as the electron donors for sulfate-reduction while acetate likely provided a carbon source. Acetate also provided a carbon and energy source for G. sulfurreducens as it used the $5 \mathrm{mM}$ fumarate as an electron-acceptor and produced succinate. The complete removal of fumarate with remaining acetate in solution indicated that the electron-acceptor limited the metabolism and growth of G. sulfurreducens. However, in other three species community culture experiments under continuous flow conditions, when $>5$ $\mathrm{mM}$ fumarate was provided, an "upset" of the steady-state co-culture often resulted that was associated with, and possibly caused by, the accumulation of succinate (data not shown). 


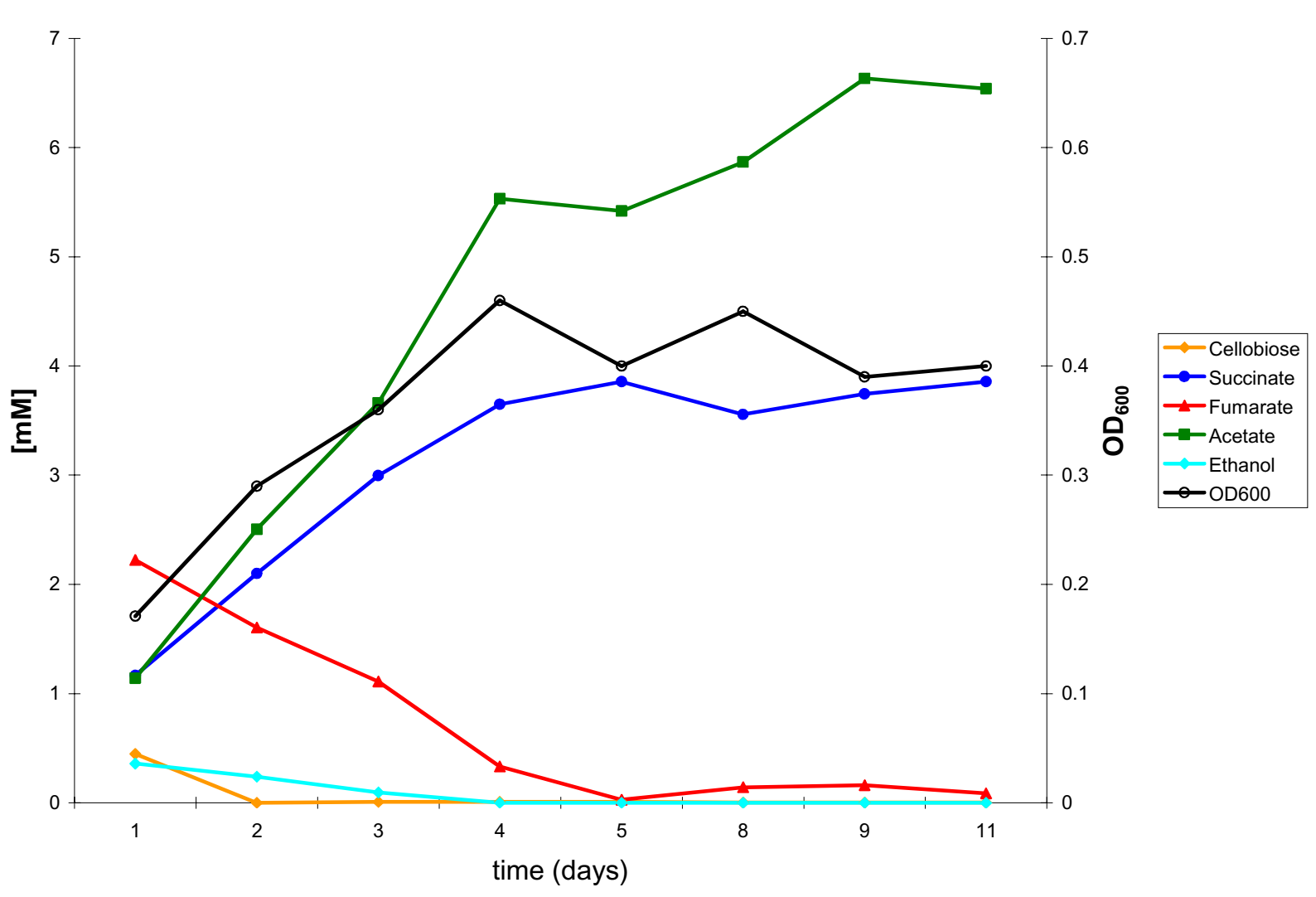

Figure 2 Metabolic monitoring of the three species community. HPLC analysis revealed the metabolite flux of the consortia. Cellobiose levels were reduced and acetate levels increased as the optical density, $\mathrm{OD}_{600}$, of the culture increased.

In addition to the HPLC analysis, sulfate depletion was measured using a commercially available kit based on the barium chloride assay [45]. These results demonstrated that $D$. vulgaris depleted $6.1 \mathrm{mM}$ sulfate (out of the $8 \mathrm{mM}$ supplied) from the medium by sulfate reduction (Additional File 1). However, sulfate remained in the medium at a concentration of about $2 \mathrm{mM}$ suggesting that $D$. vulgaris was not growth limited by the amount of sulfate available. The abundance of acetate coupled with the availability of sulfate suggests that electron donors were limiting the growth of $D$. vulgaris. Small amounts of hydrogen $(<10 \mu \mathrm{M})$ were detected in the culture gas phase as shown in Additional File 1, suggesting its availability for interspecies hydrogen transfer. However, in preliminary experiments using these same reactor conditions, these $\mathrm{H}_{2}$ concentrations proved insufficient to support the growth of Methanococcus maripaludis over sustained periods at this dilution and gas flushing rate (data not shown). It is possible that a combination of the reactor agitation rate combined with the gas exchange rate decreased the $\mathrm{H}_{2}$ partial pressure to a point where the growth of the methanogen was unsustainable.

From the metabolic analysis several conclusions can be drawn about the three species community comprised of
C. cellulolyticum, D. vulgaris, and G. sulfurreducens. Given that cellobiose was virtually exhausted in the culture supernatant, C. cellulolyticum was likely growth limited by the availability of cellobiose and not by the dilution rate which was considerably slower than the maximum growth rate observed in monoculture chemostat studies [37,46]. Analysis of the three species community's metabolism coupled with results from a $C$. cellulolyticum single species chemostat fed with a similar medium suggests that $C$. cellulolyticum produced little to no lactate under these conditions (data not shown) in agreement with previous studies $[37,46]$.

\section{Culture composition determined by quantitative $P C R$}

In order to monitor the cell numbers of the individual species comprising the three species community, a quantitative PCR (qPCR) based method was used to quantify each member of the community over time. Specific primers targeting the $16 \mathrm{~S}$ small subunit (SSU) rRNA gene for C. cellulolyticum, D. vulgaris, and G. sulfurreducens were designed and are listed in Table 1. The qPCR conditions were optimized as described in the Materials and Methods section.

As expected, the three species community was dominated by $C$. cellulolyticum with $D$. vulgaris and G. sul- 
Table 1: Oligonucleotide primers used for qPCR

\begin{tabular}{lll}
\hline Primer name & Target Organism & Sequence \\
\hline DvH-F & D. vulgaris & \\
DvH-R & D. vulgaris & $5^{\prime}$-GCGTTAAGCATCCCGCCT-3' \\
Geo-F & G. sulfurreducens & $5^{\prime}$-CATCGAATTAAACCACAT-3' \\
Geo-R & G. sulfurreducens & $5^{\prime}$-TAGCCGCCTTCGCCACCG-3' \\
Clos-F & C. cellulolyticum & $5^{\prime}-$ GATGGATACTAGGTGTAG-3' \\
Clos-R & C. cellulolyticum & $5^{\prime}$-TTCCTTTGAGTTCAACC-3' \\
\hline
\end{tabular}

furreducens present at a level at least an order of magnitude lower (Figure 3). qPCR derived estimates of cell numbers for C. cellulolyticum approached approximately $5 \times 10^{8}$ cells ml $^{-1}$ (Figure 3 and Table 2), whereas G. sulfurreducens and D. vulgaris were present in the tri-cultures approximately $10^{7}$ cells ml-1 representing roughly an order of magnitude difference. Direct cell counts of these and other tri-cultures as well as the conversion of optical density measurements to cell dry weight were in general agreement that $90 \%$ of the cells were C. cellulolyticum.
qPCR was primarily used to rapidly track the temporal dynamics of the individual species within the cultures on a daily basis, as opposed to being used to provide absolute numbers of each community member.

\section{Fluorescent microscopy confirms the presence of each species}

In order to confirm the presence of all three species in the tri-cultures as well as substantiating the dominance of $C$. cellulolyticum, a fluorescent microscopy based assay that used fluorescent antibodies specific for C. cellulolyticum

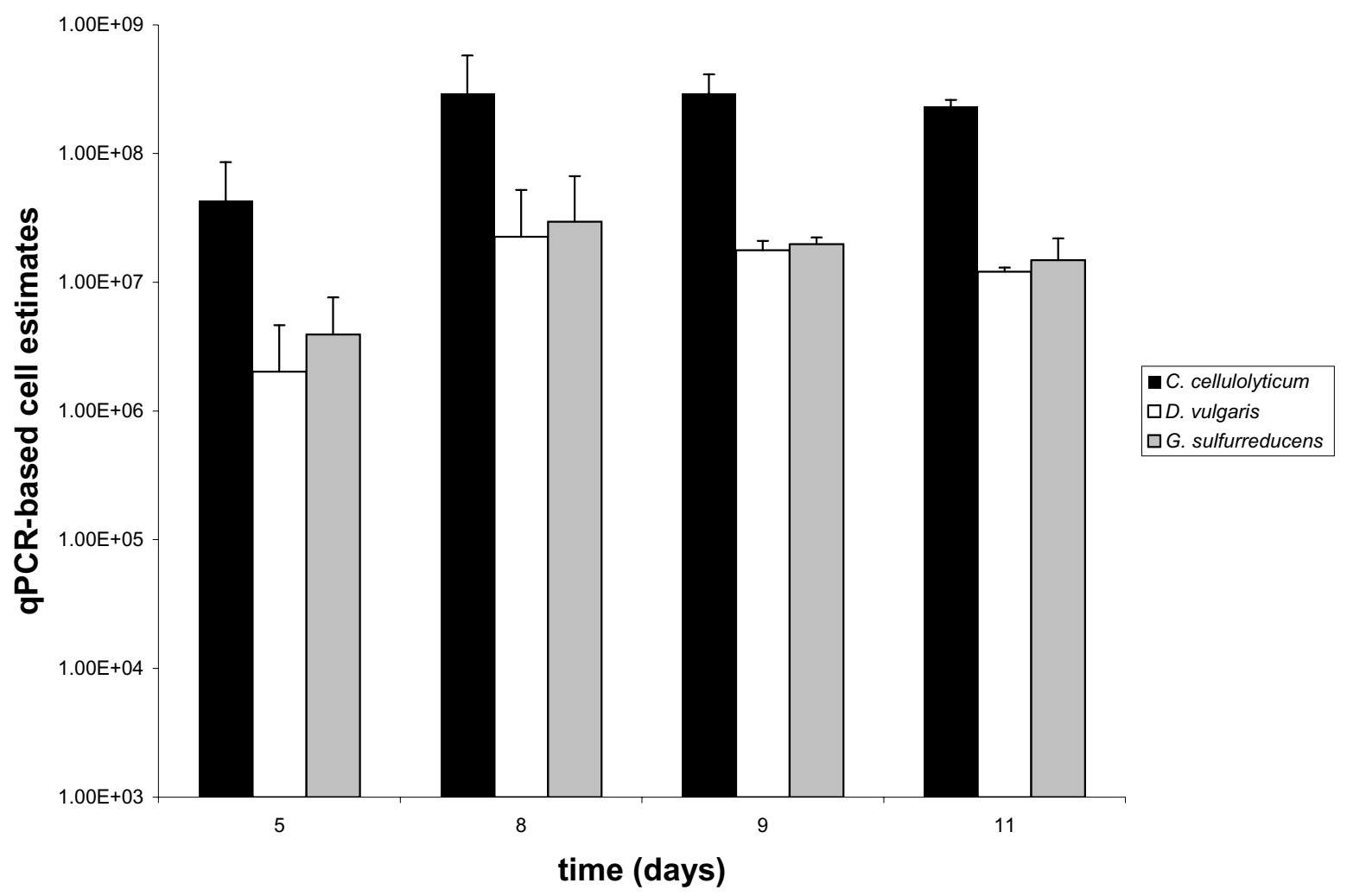

Figure 3 Cell numbers were quantified using qPCR. The number of cells of each species present in each of two three species communities was quantified using qPCR. In both communities C. cellulolyticum was the dominant member being an order of magnitude greater than G. sulfurreducens and D. vulgaris. 
Table 2: Estimated Carbon and e- Recovery of Three Species Community*

\begin{tabular}{cccccc}
\hline & $\begin{array}{c}\text { cell counts } \\
\left(\times \mathbf{~ 1 0}^{\mathbf{8}}\right)\end{array}$ & $\begin{array}{c}\text { biomass } \\
(\mathbf{m g} / \mathbf{L})\end{array}$ & C recovered & e- recovered & $\begin{array}{c}\text { energy in digestible end products } \\
(\%)\end{array}$ \\
\hline $\begin{array}{c}\text { three species } \\
\text { community }\end{array}$ & 5.25 & 236 & 93 & 112 & 45 \\
C. cellulolyticum & 4.6 & 210 & 104 & 120 & 71 \\
$\quad$ D. vulgaris & 0.29 & 13 & 112 & 122 & 7 \\
G. sulfurreducens & 0.36 & 16 & 79 & 83 & 78 \\
\hline
\end{tabular}

* italicized values are based on the model shown in Figure 5 .

and D. vulgaris with DNA specific fluorescent dye 4',6diamidino-2-phenylindole (DAPI) was employed. Samples of a three species community were collected, fixed with paraformaldehyde, stained with the labeled antibodies and DAPI are shown in Figure 4. Figure 4A shows a similarly stained artificial mixture of cultures of the three individual species combined in an approximate 1:1:1 ratio of cell numbers to demonstrate the sensitivity of the assay to detect cells of each species. C. cellulolyticum cells were red, D. vulgaris cells were green, and G. sulfurreducens cells were blue. The arrows indicate representative cells of each species. Figure 4B shows a sample of the three species community showing the presence of all three species and substantiating the dominance of $C$. cellulolyticum representing nearly $90 \%$ of the community with microscopic cell counts averaging $5 \times 10^{8}$ per $\mathrm{ml}$ (Table 2).

\section{Proposed Carbon and Electron Flow}

A model of carbon and electron flow for the three species community was derived from measurements of the three species community steady-state, single culture chemostat experiments, and data from the literature (Figure 5 and Additional File 1 and Table 2). The $640 \mathrm{ml}$ chemostat triculture exhibited an $\mathrm{OD}_{600}$ of 0.4 with a $236 \mathrm{mg}$ dry weight per liter of biomass. Based on qPCR ratios an approximation was made for each population and used in the model (Table 2 and Figure 5). The overall carbon recovery was estimated at $93 \%$ when including cell mass. When modeled for the three populations the values ranged between $79-112 \%$. Similarly, the overall electron recovery was $112 \%$ with the individual population models ranging from $83-122 \%$. There was a larger loss of sulfate than readily accounted for causing a modeled electron recovery greater than $120 \%$ for $D$. vulgaris, while a loss of carbon in the fumarate-malate-succinate pool resulted in a lower carbon and electron recovery for G. sulfurreducens. Because succinate is a readily metabolized end product, $78 \%$ of the energy modeled to enter G. sulfurreducens was still in some digestible form that could potentially be available for additional microorganisms representing other trophic groups in future experiments.
On the other hand, sulfide generation by $D$. vulgaris is of little value for other anaerobic trophic groups. Importantly, $71 \%$ of the end products from C. cellulolyticum were potentially digestible by other anaerobic trophic groups, and consumption of nearly half of those were evidenced in three-species community described here (Table 2 and Figure 5). The addition of an acetate utilizing methanogen could potentially be envisioned as additional consortia member in this arrangement, however no organisms were readily available that met our other selection criteria (sequenced genome, genetically manipulable, and additionally non-clumping as necessary for efficient chemostat growth).

In the proposed model describing the metabolism of the three species community culture, the culture feed concentration of $2.2 \mathrm{mM}$ cellobiose was completely consumed by the C. cellulolyticum with the major end product being $5.93 \mathrm{mM}$ acetate and a similar quantity of $\mathrm{CO}_{2}$. A combined 3.3 moles of carbon dioxide was produced by C. cellulolyticum and G. sulfurreducens, but not by D. vulgaris which has an incomplete TCA cycle [32]. Each mole of cellobiose led to 2.7 moles acetate in the supernatant while approximately 0.7 moles of acetate equivalents likely went towards either the electron donating food source of the Geobacter or into the biomass of the Geobacter and Desulfovibrio cells. Hydrogen and ethanol, though generally below detectable limits in tri-culture chemostats, were likely produced by $C$. cellulolyticum and used by $D$. vulgaris to reduce 2.7 moles of sulfate to hydrogen sulfide. The ratio of ethanol and hydrogen available to the sulfate reducer was estimated from the ratio of acetate:ethanol:hydrogen from a pure culture chemostat of $C$. cellulolyticum under the same physical and media conditions (data not shown). However, it was not clear what form of electron equivalents (hydrogen, interspecies electron transfer, or ethanol) was consumed by the sulfate reducer and this could not be distinguished in our measurements so the modeled values are considered preliminary (indicated by the circle in Figure 5). Hydrogen, though abundant in C. cellulolyticum pure culture batch experiments, was generally below detect- 
A.
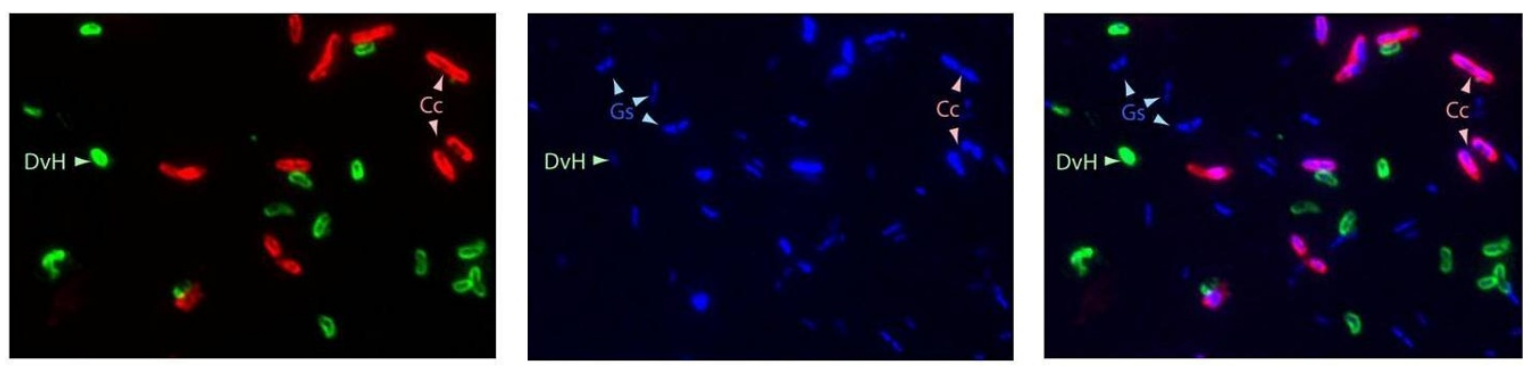

B.
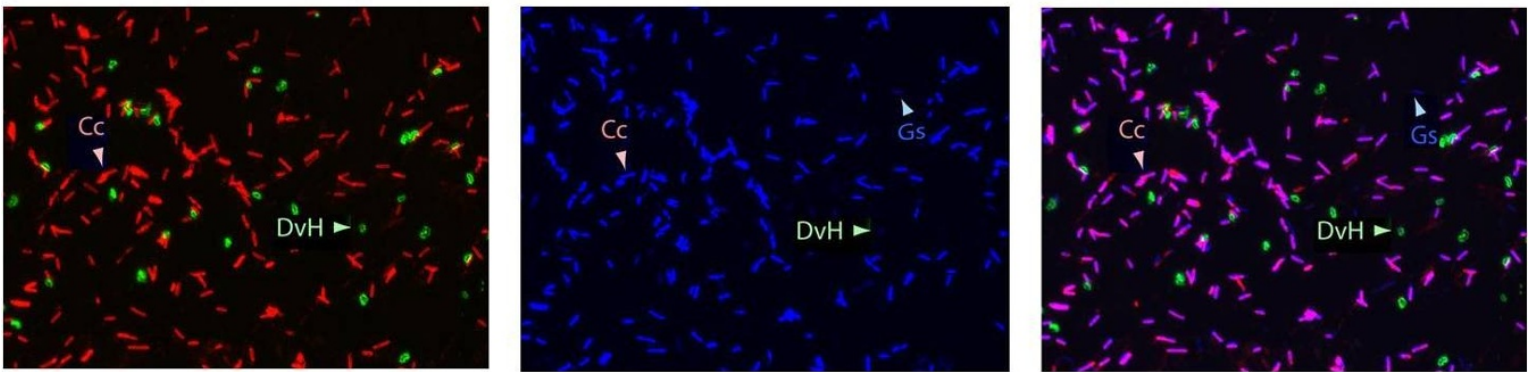

Figure 4 Fluorescent microscopy confirmed cell ratios. Fluorescent microscopy using labeled antibodies confirmed the presence of each species in the community. Samples were stained with DAPI and fluorescently labeled antibodies: green for D. vulgaris and red for C. cellulolyticum. G. sulfurreducens cells were stained blue by DAPI as described in the Materials and Methods section. (A) An artificial mixture of 1:1:1, C. cellulolyticum: D. vulgaris:G. sulfurreducens. Each image was of the same microscopic field. Two separate images taken at different fluorescent wavelengths were merged to form the image on the left showing C. cellulolyticum and D. vulgaris. The image in the center was taken with DAPI and all cells are visible. The image on the right resulted from merging the fluorescent and DAPI images and reveals the G. sulfurreducens cells as stained blue by DAPI. (B) The three species community culture shown in Figure 2 and described in the text was sampled during steady state growth and stained with DAPI and fluorescently labeled antibodies and merged as described above for (A). For (A) and (B) Arrows indicate the same cells of C. cellulolyticum, C.C., D. vulgaris, DvH, and G. sulfurreducens, G.s., imaged under the different conditions.

able limits in the three species community, being less than $0.1 \mathrm{mM}$ consumed. D. vulgaris, consumed $6.1 \mathrm{mM}$ sulfate (2.7 per mole of cellobiose consumed) leaving behind $2 \mathrm{mM}$ while both hydrogen and ethanol were not detectable suggesting its growth was likely limited by the availability of electron donors. It was possible $D$. vulgaris used fumarate as an electron donor producing succinate and acetate [47] but that was unlikely in the presence of excess sulfate. Fumarate disproportionation would have produced more acetate and succinate and would have resulted in slow growth rates approaching the chemostat dilution rate. Complex interplays of fumarate, malate, succinate, and acetate between the D. vulgaris and G. sulfurreducens were possible, with the proposed modeled framework (Figure 5) representative of carbon flow and likely electron flow.

Geobacter sulfurreducens likely utilized approximately 0.45 moles acetate per mole of cellobiose consumed. Approximately 0.3 moles acetate was modeled as the electron donor producing 0.6 moles $\mathrm{CO}_{2}$ with a minor fraction of the acetate incorporated into biomass. While $4.9 \mathrm{mM}$ fumarate was provided to the tri-culture, 2.23 moles of fumarate were transformed per mole of cellobiose consumed. The 2.23 moles of fumarate were reduced to 1.63 moles of succinate with 0.02 moles of malate also detected. Incomplete recovery of the fumarate-malatesuccinate couple may be due to some carbon potentially diverted to biomass. G. sulfurreducens was electron acceptor limited as verified by its complete removal of fumarate, and being electron acceptor limited likely facilitated electron equivalents being available for sulfate reduction. However, that limitation was forced by an apparent inhibition of the $C$. cellulolyticum whenever succinate approached $10 \mathrm{mM}$ in experiments with elevated fumarate levels (data not shown).

The model of the three species community culture accounts for $236 \mathrm{mg}$ per liter biomass corresponding to $5.25 \times 10^{8}$ cells per ml. Based upon PCR amplification ratios and cell counts, nearly $80 \%$ of the community was comprised of $C$. cellulolyticum with minor contributions by G. sulfurreducens and D. vulgaris (Figure 5 and Additional File 1). Biomass was ascribed a molecular weight of $104 \mathrm{~g} / \mathrm{M}$ based on the $\mathrm{C}_{4} \mathrm{H}_{7} \mathrm{O}_{1.5} \mathrm{~N}+$ minerals formula with the oxidation of said mole requiring 17 electron equivalents of $\sim-0.3 \mathrm{mV}$ as described by Harris and Adams 1979 [48]. Accordingly, mass balance determinations accounted for $93 \%$ of the carbon and $112 \%$ of the electrons available to the tri-culture. 


\section{Proposed Model of Three Species Community Metabolism in Molar Units}

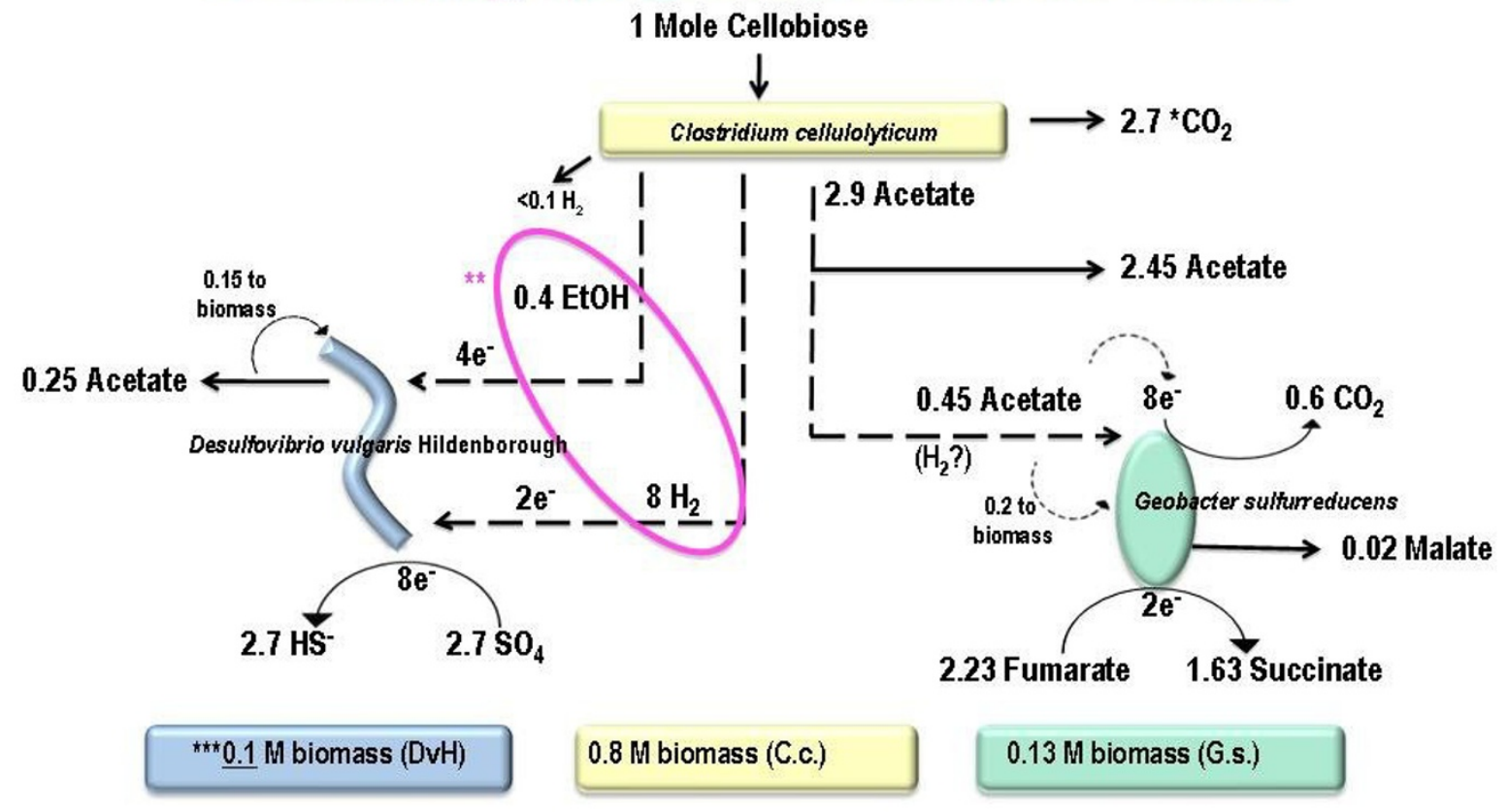

Figure 5 Proposed model of the metabolic flux and carbon and electron balance of the three member community. ${ }^{*}$ Values given are in moles. ${ }^{* *}$ Circled electron equivalents could be hydrogen, interspecies electron transfer, or ethanol. See text for details. ${ }^{* * *} \mathrm{~N}$-moles of biomass determined according to $\mathrm{C}_{4} \mathrm{H}_{7} \mathrm{O}_{1.5} \mathrm{~N}+$ minerals, $104 \mathrm{gMW}$ (Harris and Adams, 1979). Note: The underlined biomass value $(\underline{0.1})$ was used for calculations in Additional File 1.

\section{Conclusions}

These results demonstrate that C. cellulolyticum, D. vulgaris, and G. sulfurreducens can be grown in coculture in a continuous culture system in which $D$. vulgaris and $G$. sulfurreducens are dependent upon the metabolic byproducts of C. cellulolyticum for nutrients. Moreover, the overall cell densities achieved and maintained under these conditions were appropriate for observing changes in the cell densities resulting from growth or decline from perturbations of nutrients or by stress conditions. Effective methods have been developed to monitor population dynamics and metabolic fluxes of the coculture. This represents a step towards developing a tractable model ecosystem comprised of members representing the functional groups of a trophic network.

Future studies will aim to add additional complexities with the goal of better representing subsurface communities and conditions, as well as responses after perturbing the systems with various stresses (i.e. high salt concentrations, nitrate load, and varying $\mathrm{pH}$ conditions) in order to determine how the individual members and the community respond in terms of growth rate and metabolic activ- ity. Efforts are also underway to apply systems biology level approaches, including for example microarrays to determine expression levels of key metabolic genes during the shift to coculture growth as well as during artificially-induced physical and chemical stress.

\section{Methods}

\section{Strains and Growth Medium}

Bacterial strains used in this study were as follows: Clostridium cellulolyticum H10 (ATCC 35319), Desulfovibrio vulgaris subsp. vulgaris Hildenborough NCIMB 8303 [49], and Geobacter sulfurreducens [50]. B3M medium as described by Stolyar et al. 2007 [15] was modified to support the growth of $C$. cellulolyticum and called B3A. Notably, the buffering agent was changed to 3-(nmorpholino)propanesulfonic acid (MOPS) due to its greater buffering capacity to cope with the fermentation by $C$. cellulolyticum and eliminate the need for continuous $\mathrm{pH}$ adjustment of the cultures. B3A medium contained (per liter) $3 \mathrm{~g} \mathrm{NaCl}, 0.5 \mathrm{~g} \mathrm{MgCl}_{2} \cdot 6 \mathrm{H} 2 \mathrm{O}, 1 \mathrm{~g} \mathrm{NH}_{4} \mathrm{Cl}$, $0.1 \mathrm{~g} \mathrm{KCl}, 2 \mathrm{~g} \mathrm{3-(n-morpholino)propanesulfonic} \mathrm{acid}$ (MOPS), and $0.2 \mathrm{mg}$ resazurine added to milli-Q water. 
The $\mathrm{pH}$ was adjusted to 7.2 prior to autoclaving. The following compounds were added from stock solutions after autoclaving to the final concentration shown: $0.2 \mathrm{nM} \mathrm{L-}$ alanine, $1 \mathrm{mM} \mathrm{CaCl}, 2.2 \mathrm{mM}$ cellobiose, $0.2 \%$ cysteine, 5 $\mathrm{mM}$ fumarate, $5 \mathrm{mM} \mathrm{NaHCO}, 8 \mathrm{mM} \mathrm{Na}_{2} \mathrm{SO}_{4}$, and 10 $\mathrm{mM} \mathrm{K}_{2} \mathrm{HPO}_{4} 2 \mathrm{ml}$ per liter of a vitamin solution (containing per liter $0.02 \mathrm{~g}$ biotin, $0.02 \mathrm{~g}$ folic acid, $0.1 \mathrm{~g}$ pyridoxine $\mathrm{HCl}, 0.05 \mathrm{~g}$ thiamine $\mathrm{HCl}, 0.05 \mathrm{~g}$ riboflavin, $0.05 \mathrm{~g}$ nicotinic acid, $0.05 \mathrm{~g}$ calcium pantothenate, $0.05 \mathrm{~g} \mathrm{p}$ aminobenzoic acid, $0.01 \mathrm{~g}$ vitamin $\mathrm{B} 12,0.05 \mathrm{~g}$ thioctic acid), and $1 \mathrm{ml}$ per liter of a trace minerals solution (containing per liter $0.2 \mathrm{~g} \mathrm{FeCl}_{2} \cdot 4 \mathrm{H}_{2} \mathrm{O}, 0.1 \mathrm{~g} \mathrm{MnCl}_{2} \cdot 4 \mathrm{H}_{2} \mathrm{O}, 0.1$ g CoCl $2 \cdot 2 \mathrm{H}_{2} \mathrm{O}, 0.05 \mathrm{~g} \mathrm{ZnCl}_{2}, 0.01 \mathrm{~g} \mathrm{Na}_{2} \mathrm{MoO} 4,0.005 \mathrm{~g}$ $\mathrm{H}_{3} \mathrm{BO}_{3}, 0.024 \mathrm{~g} \mathrm{NiCl}_{2} \cdot 6 \mathrm{H}_{2} \mathrm{O}, 0.002 \mathrm{~g} \mathrm{CuCl}_{2} \cdot 2 \mathrm{H}_{2} \mathrm{O}, 0.017 \mathrm{~g}$ $\mathrm{Na}_{2} \mathrm{SeO}_{3} \cdot 5 \mathrm{H}_{2} \mathrm{O}, 0.020$ g Na${ }_{2} \mathrm{WO}_{4} \cdot 2 \mathrm{H}_{2} \mathrm{O}, 1.5 \mathrm{~g}$ nitrilotriacetic acid, $0.1 \mathrm{~g} \mathrm{MgCl}_{2} \cdot 6 \mathrm{H}_{2} \mathrm{O}, 1 \mathrm{~g} \mathrm{CaCl} \cdot 2 \mathrm{H}_{2} \mathrm{O}$ ) was also added after autoclaving.

\section{Reactor Operation}

Two replicate custom built anaerobic glass fermentation vessels (Allen Glass, Boulder, $\mathrm{CO}$ ) with working volumes of approximately $650 \mathrm{ml}$ were filled with B3A medium (Figure 1). The fermentation vessels were fed medium from the same carboy by individual peristaltic pumps set to deliver media at a flow rate of $0.34 \mathrm{ml} \mathrm{min}^{-1}$ (Figure 1) which was equivalent to a dilution rate of $0.03 \mathrm{~h}^{-1}$. The headspace of the $19 \mathrm{~L}$ carboy was flushed with $\mathrm{N}_{2}$ at $\sim 10$

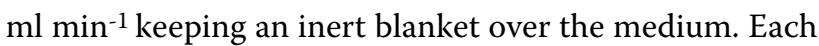
fermentation vessel was constantly stirred via a magnetic stir bar and anaerobic conditions were maintained by a constant flow of nitrogen gas $\left(49 \mathrm{ml} \mathrm{min}^{-1}\right)$ through the medium inlet tube. Sparging the inlet drip-tube proved instrumental in reducing biofilm development in the medium dispensing system and allowed for the prevention of microbial contamination in the sterile medium carboy over four of weeks of operation. The temperature was maintained constant at $30^{\circ} \mathrm{C} \pm 2^{\circ} \mathrm{C}$ by circulating water through the water jackets of each fermentation vessel via a recirculating water bath. Spent culture fluid was allowed to drain out of the vessel overflow vent into a closed collection vessel at the same rate as the replenishing medium thereby maintaining a constant volume. Gas exited the fermentation vessel in the same manner and the collection vessel off gas was passed through an acidified $\mathrm{Zn}$-acetate solution ( $1 \%$ mass to volume) in order to remove hydrogen sulfide before being vented into a chemical fume hood. Gas samples were taken with needles and syringes through ports at the top of the vessels that were sealed with butyl rubber bungs. Liquid samples were taken from the media overflow tubing.

\section{Genomic DNA Isolation}

Total genomic DNA was isolated from the bacterial cocultures by using the Wizard Genomic DNA purification kit (Promega) according to the manufacturer's protocol with slight modifications. Briefly, $10 \mathrm{ml}$ of co-culture samples were harvested and resuspended in $520 \mu \mathrm{l}$ of 50 mM EDTA. The cells were further treated with $30 \mu \mathrm{l}$ of $100 \mathrm{mg} / \mathrm{ml}$ lysozyme and incubation at $37^{\circ} \mathrm{C}$ for $30 \mathrm{~min}-$ utes followed by addition of $10 \mu \mathrm{l}$ of $10 \mathrm{mg} / \mathrm{ml}$ proteinase $\mathrm{K}$ and further incubation at $37^{\circ} \mathrm{C}$ for 30 minutes. Cell lysis and RNase treatment were performed according to the manufacturer's recommendations. DNA was precipitated with a 0.6 volume of isopropanol, and dissolved in $100 \mu \mathrm{l}$ TE buffer. The concentration and purity of both DNA and RNA samples were determined by spectrophotometric ratio assay at $260 \mathrm{~nm}$ and $280 \mathrm{~nm}$ using a Nanodrop spectrophotometer.

\section{Quantitative Polymerase Chain Reaction (qPCR) Assay}

A qPCR assay was employed to monitor the population dynamics of individual bacterial species in the co-culture. Specific primers targeting $16 \mathrm{~S}$ rRNA genes to track the abundance of individual species in the co-culture via qPCR were designed (Table 1). All assays were performed with the CFX96 ${ }^{\mathrm{TM}}$ Real Time Detection System (Bio-Rad, Herculus, CA). The fluorescent intensity of SYBR green I, a double-stranded DNA specific dye, was monitored at the end of each extension step, and copy numbers of the target DNAs were estimated by the threshold cycles according to a standard curve. Standard curves were constructed for each organism using their respective genomic DNA and taking into account known genome sizes and copy number. The PCR amplifications were performed in microtiter plates as $30 \mu \mathrm{l}$ reactions containing the appropriate primers at a final concentration of 0.4 $\mu \mathrm{M}, 0.5 \mu \mathrm{l}$ of the DNA extract, and SYBR green supermix (Bio-Rad, Herculus, CA). Amplification was accomplished by incubating the PCR mixture at $96^{\circ} \mathrm{C}$ for $15 \mathrm{~s}$, $55^{\circ} \mathrm{C}$ for $30 \mathrm{~s}$, and $72^{\circ} \mathrm{C}$ for $30 \mathrm{~s}$ for 45 cycles. Melting curve generation followed the amplification, starting at $55^{\circ} \mathrm{C}$, with $0.5^{\circ} \mathrm{C}$ increments at 10 second intervals. For each time point, there were 3 biological replicates and 3 technical replicates in the same plate. qPCR standard curves were constructed using serial dilutions of total genomic DNA for all three bacterial The following equation was used to calculate the number of $16 \mathrm{~S}$ rRNA gene copy numbers in a known amount of DNA:

number of copies $=\left(\right.$ amount $\left.* 6.022 \times 10^{23}\right) /\left(\right.$ length $\left.* 1 \times 10^{9} * 650\right)$

where amount is total amount of DNA in ng and length is the total length of DNA in bp. To obtain the $16 \mathrm{~S}$ rRNA genes copies per $\mathrm{ml}$, the gene copy numbers obtained from the standard curves was multiplied by the total volume of extracted DNA and divided by the volume of sample from which the DNA was extracted and the number of $16 \mathrm{~S}$ rRNA gene copies for each organism (eight copies 
for $C$. cellulolyticum, five copies for D. vulgaris and two copies for G. sulfurreducens).

\section{Metabolite Analysis}

Filtered supernatants were acidified with $200 \mathrm{mM}$ sulfuric acid (giving a final concentration of $5 \mathrm{mM}$ ) before injection into a Hitachi Lachrom Elite HPLC system (Hitachi High Technologies, USA). Metabolites were separated on an Aminex HPX-87H column (BioRad Laboratories) under isocratic temperature $\left(40^{\circ} \mathrm{C}\right)$ and flow $(0.5$ $\mathrm{ml} / \mathrm{min}$ ) conditions then passed through a refractive index (RI) detector (Hitachi L-2490). Identification was performed by comparison of retention times with known standards. Quantitation of the metabolites was calculated against linear standard curves. All standards were prepared in uninoculated culture media to account for interference of salts in the RI detector.

Gases were collected from the fermenter vessel headspace via $5 \mathrm{ml}$ syringes and stored at room temperature in $10 \mathrm{ml}$ anaerobic serum bottles from which $5 \mathrm{ml}$ of gas was removed before being analyzed on an Agilent 6850 gas chromatograph (Agilent Technologies, USA) equipped with a thermal conductivity detector (TCD). All gas analytes were separated on an HP-PLOT U column $(30 \mathrm{~m} \times$ $0.32 \mathrm{~mm} \times 0.10$ um film) (J\&W Scientific, Agilent Technologies, USA). Two HP-PLOT U columns were joined together for a total length of $60 \mathrm{~m}$ for optimized separation. Samples for carbon dioxide and hydrogen sulfide measurements were injected into a $185^{\circ} \mathrm{C}$ split-splitless injector with the split ratio set to $3: 1$ and isocratic oven $\left(70^{\circ} \mathrm{C}\right)$ and helium carrier flow $(5.1 \mathrm{ml} / \mathrm{min})$. The detector had $10 \mathrm{ml} / \mathrm{min}$ helium makeup flow at $185^{\circ} \mathrm{C}$, with the detector filament set for positive polarity. Samples to detect hydrogen concentrations were injected into a $185^{\circ} \mathrm{C}$ split-splitless injector with a split ratio of 3:1 and isocratic oven $\left(180^{\circ} \mathrm{C}\right)$ and nitrogen carrier flow $(3.5 \mathrm{ml} /$ $\mathrm{min}$ ). The detector had $10 \mathrm{ml} / \mathrm{min}$ nitrogen makeup flow at $185^{\circ} \mathrm{C}$ with the detector filament at negative polarity. Peak identifications were performed by comparison with known standards. Quantification of each compound was calculated against individual linear standard curves. Henry's Law was used to calculate the solubility of the gases in the media. For carbon dioxide, a modified Henry's Law calculation accounting for the chemical reactivity of the gas was used to determine the amount of gas in solution [51].

Sulfate concentrations were measured using the Sulfaver 4 kit according to Hach Company's instructions. Aqueous hydrogen sulfide was determined by a colorimetric method developed by Pachmayr and described by Brock et al. 1971 [52].

\section{Fluorescence Microscopy and Direct Cell Counts}

Cells were fixed in $4 \%$ paraformaldehyde for $20 \mathrm{~min}$ at room temperature and washed 3 times in phosphate buffered saline (PBS; $137 \mathrm{mM} \mathrm{NaCl}, 10 \mathrm{mM}$ phosphate, 2.7
$\mathrm{mM} \mathrm{KCl}[\mathrm{pH} 7.4])$ and resuspended in PBS. The fixed cells ( 2 to $5 \times 10^{6}$ cells) were collected on a $0.2-\mu \mathrm{m}$ black polycarbonate filter (Millipore, Isopore GTPB 02500), and the cells on the filter were transferred to $0.1 \%$ gelatin coated slides which contained 5 microliters of water by applying a vacuum for 5 minutes to transfer the cells to the slides [53]. The cells were incubated with fluorophore conjugated polyclonal antibodies FITC for $D$. vulgaris and Rhodamine for C. cellulolyticum for $30 \mathrm{~min}$ at room temperature, washed with PBS three times, and subsequently were stained with DAPI (4',6'-diamidino-2-phenylindole) $3 \mu \mathrm{M}$ for 15 minutes. SlowFade Gold from Invitrogen was applied to the slides and the slides were mounted on a Zeiss AX10 microscope. Images were taken by a black and white AxioCam MRm digital camera (Carl Zeiss, Inc.) and then colorized to the appropriate color and merged using photo editing software. Microscopic direct counts of cells were performed using a Petroff Hausser Counting Chamber using a Zeiss Axioskop 2 plus microscope.

\section{Carbon and Electron Balance and Metabolic Modeling}

The metabolic model of the three species community including the carbon and electron balance was designed based on the replicate fermenter steady-state and single culture chemostats and was complemented by batch culture experiments and data from the literature.

For a $640 \mathrm{ml}$ culture with an $\mathrm{OD}_{600}$ of 0.4 , the biomass was $236 \mathrm{mg} \mathrm{dw} / \mathrm{L}$ based on a cell dry weight biomass of $590 \mathrm{mg} \mathrm{dw} / \mathrm{L}$ for a C. cellulolyticum culture with an $\mathrm{OD}_{600}$ of 1.0 and $1.3 \times 10^{9}$ cells $/ \mathrm{ml}$. The $236 \mathrm{mg}$ per liter biomass corresponded to $5.25 \times 10^{8}$ cells per ml. Fractions of the specific populations were based upon PCR amplification ratios and cell counts. Biomass was ascribed a molecular weight of $104 \mathrm{~g} / \mathrm{M}$ based on the $\mathrm{C}_{4} \mathrm{H}_{7} \mathrm{O}_{1.5} \mathrm{~N}+$ minerals formula with the oxidation of said mole requiring 17 electron equivalents of $\sim-0.37 \mathrm{mV}$ as described by Harris and Adams 1979 [47].

Carbon and electron balances in Tables 2 and 1 were based on the model (Figure 5) and analytics, accomplished by comparing carbon inputs with products. The electron balance was based on electron equivalents of inputs compared to electron equivalents of products, including biomass as described above. The fraction of energy available in digestible end products was based on the number of electron equivalents and their energies of all substrates as compared to the energy of the electron equivalents in readily digestible end products such as acetate, succinate, ethanol or hydrogen but excluding biomass or sulfide.

\section{Additional material}

Additional file 1 Carbon Flow Table. A table showing the measured and modeled carbon flow of the three species community and populations. 


\section{Authors' contributions}

LM performed the continuous culture experiments, analyzed the data, and drafted the manuscript. JM performed the metabolic analysis. AV performed the quantitative $P C R$ analysis. ZY performed the fluorescent antibody experiments. AP, TP, MP, CS, and MK conceived of the study, and participated in its design and coordination. All authors read and approved the final manuscript.

\section{Acknowledgements}

The authors would like to thank Meghan Drake for culturing assistance. We also thank two anonymous reviewers for helpful comments. This work was part of work by the Virtual Institute for Microbial Stress and Survival http:// vimss.lbl.gov/sponsored by the U.S. Department of Energy, Office of Science, and Office of Biological and Environmental Research Genomics:GTL program. Oak Ridge National Laboratory is managed by UT Battelle, LLC, for the U.S. Department of Energy under contract DE-ACO5-00OR22725.

\section{Author Details}

'Biosciences and Environmental Sciences Division, Oak Ridge National Laboratory, Oak Ridge, TN 37831, USA and 2Virtual Institute for Microbial Stress and Survival, LBNL One Cyclotron Road MS 977-152 Berkeley, CA 94720, USA

Received: 9 December 2009 Accepted: 24 May 2010

Published: 24 May 2010

\section{References}

1. Macfarlane GT, Macfarlane S: Models for intestinal fermentation: association between food components, delivery systems, bioavailability and functional interactions in the gut. Curr Opin Biotechnol 2007, 18:156-62.

2. Turnbaugh PJ, Ley RE, Hamady M, Fraser-Liggett CM, Knight R, Gordon Jl: The human microbiome project. Nature 2007, 18:804-810,

3. Faloney G, Calmeyn T, Leroy F, De Voyst L: Coculture fermentation of Bifobacterium species and Bacteroides thetaiotaomicron reveal a mechanistic insight into the prebiotic effect of inulin-type fructans. Appl Environ Microbiol 2009, 75:2312-2319.

4. Viñas M, Sabaté J, Guasp C, Lalucat J, Solanas AM: Culture-dependent and -independent approaches establish the complexity of a PAHdegrading microbial consortium. Can J Microbiol 2005, 51:897-909.

5. Peng RH, Xiong AS, Xue Y, Fu XY, Gao F, Zhao W, Tian YS, Yao QH: Microbial biodegradation of polyaromatic hydrocarbons. FEMS Microbiol Rev 2008, 32:927-955.

6. Haritash AK, Kaushik CP: Biodegradation aspects of polycyclic aromatic hydrocarbons (PAHs): a review. J Hazard Mater 2009, 30:1-15.

7. Wagner M, Loy A: Bacterial community composition and function in sewage treatment systems. Curr Opin Biotechnol 2002, 13:218-227.

8. Daims H, Taylor MW, Wagner M: Wastewater treatment: a model system for microbial ecology. Trends Biotechnol 2006, 24:483-489.

9. Rittmann BE, Hausner M, Löffler F, Love NG, Muyzer G, Okabe S, Oerther $\mathrm{DB}$, Peccia J, Raskin L, Wagner M: A vista for microbial ecology and environmental biotechnology. Environ Sci Technol 2006, 40:1096-1103.

10. Morita RY: Bioavailability of energy and its relationship to growth and starvation survival in nature. J Can Microbiol 1988, 43:436-441.

11. Egli T: The ecological and physiological significance of the growth of heterotrophic microorganisms with mixtures of substrates. Adv Microb Ecol 1995, 14:305-386.

12. Harms H, Bosma TNP: Mass transfer limitation of microbial growth and pollutant degradation. J Ind Microbiol 1997, 18:97-105.

13. Kovárová-Kovar K, Egli T: Growth kinetics of suspended microbial cells: from single-substrate-controlled growth to mixed substrate kinetics. Microbiol Mol Biol Rev 1998, 62:646-666.

14. Elias DA, Tollaksen SL, Kennedy DW, Mottaz HM, Giometti CS, McLean JS, Hill EA, Pinchuk GE, Lipton MS, Fredrickson JK, Gorby YA: The influence of cultivation methods on Shewanella oneidensis physiology and proteome expression. Arch Microbiol 2008, 189:313-24.

15. Stolyar S, Van Dien S, Hillesland KL, Pinel N, Lie TJ, Leigh JA, Stahl DA Metabolic modeling of a mutualistic microbial community. Mol Syst Biol 2007, 3:1-14.

16. Schink B: Synergistic interactions in the microbial world. Antonie Van Leeuwenhoek 2002, 81:257-261.

17. Hardin G: The competitive exclusion principle. Science 1960, 29:1292-7.
18. Armstrong AA, McGehee R: Competitive exclusion. Am Nat 1980 115:151-170.

19. Hsu SB, Hubbell S, Waltman P: A Mathematical Theory for SingleNutrient Competition in Continuous Cultures of Micro-Organisms. SIAM Journal on Appl Mathematics 1977, 32:366-383.

20. Lenski RE, Hattingh SE: Coexistence of two competitors on one resource and one inhibitor: A chemostat model based on bacteria and antibiotics. J Theor Biol 1986, 122:83-96.

21. Fernández A, Huang S, Seston S, Xing J, Hickey R, Criddle C, Tiedje J: How stable is stable? Function versus community composition. App/Environ Microbiol 1999, 65:3697-3704.

22. von Canstein H, Li Y, Wagner-Döbler I: Long-term performance of bioreactors cleaning mercury-contaminated wastewater and their response to temperature and mercury stress and mechanical perturbation. Biotechnol Bioeng 2001, 74:212-219.

23. Briones A, Raskin L: Diversity and dynamics of microbial communities in engineered environments and their implications for process stability. Curr Opin Biotechnol 2003, 14:270-276.

24. Chen J, Gu B, LeBoeuf EJ, Pan H, Dai S: Spectroscopic characterization of the structural and functional properties of natural organic matter fractions. Chemosphere 2002, 48:59-68.

25. Chen J, LeBoeuf EJ, Dai S, Gu B: Fluorescence spectroscopic studies of natural organic matter fractions. Chemosphere 2003, 50:639-647.

26. Phelps TJ, Murphy EM, Pfiffner SM, White DC: Comparison between geochemical and biological estimates of subsurface microbial activities. Microb Ecol 1994, 28:335-349.

27. Anderson RT, Vrionis HA, Ortiz-Bernad I, Resch CT, Long PE, Dayvault R, Karp K, Marutzky S, Metzler DR, Peacock A, White DC, Lowe M, Lovley DR: Stimulating the in situ activity of Geobacter species to remove uranium from the groundwater of a uranium-contaminated aquifer. Appl Environ Microbiol 2003, 69:5884-5891.

28. North NN, Dollhopf SL, Petrie L, Istok JD, Balkwill DL, Kostka JE: Change in bacterial community structure during in situ biostimulation of subsurface sediment cocontaminated with uranium and nitrate. App Environ Microbiol 2004, 70:4911-4920.

29. Chang YJ, Peacock AD, Long PE, Stephen JR, McKinley JP, Macnaughton SJ, Hussain AK, Saxton AM, White DC: Diversity and characterization of sulfate-reducing bacteria in groundwater at a uranium mill tailings site. Appl Environ Microbiol 2001, 67:3149-3160.

30. Elias DA, Krumholz LR, Wong D, Long PE, Suflita JM: Characterization of microbial activities and $U$ reduction in a shallow aquifer contaminated by uranium mill tailings. Microb Ecol 2003, 46:83-91.

31. Methé BA, Nelson KE, Eisen JA, Paulsen IT, Nelson W, Heidelberg JF, Wu D, Wu M, Ward N, Beanan MJ, Dodson RJ, Madupu R, Brinkac LM, Daugherty SC, DeBoy RT, Durkin AS, Gwinn M, Kolonay JF, Sullivan SA, Haft DH, Selengut J, Davidsen TM, Zafar N, White O, Tran B, Romero C, Forberger HA, Weidman J, Khouri H, Feldblyum TV, Utterback TR, Van Aken SE, Lovley DR, Fraser CM: Genome of Geobacter sulfurreducens: metal reduction in subsurface environments. Science 2003, 12:1967-1969.

32. Heidelberg JF, Seshadri R, Haveman SA, Hemme CL, Paulsen IT, Kolonay JF, Eisen JA, Ward N, Methe B, Brinkac LM, Daugherty SC, Deboy RT, Dodson RJ, Durkin AS, Madupu R, Nelson WC, Sullivan SA, Fouts D, Haft DH, Selengut J, Peterson JD, Davidsen TM, Zafar N, Zhou L, Radune D, Dimitrov G, Hance M, Tran K, Khouri H, Gill J, Utterback TR, Feldblyum TV, Wall JD, Voordouw G, Fraser CM: The genome sequence of the anaerobic, sulfate-reducing bacterium Desulfovibrio vulgaris Hildenborough. Nat Biotechnol 2004, 22:554-9.

33. Bender KS, Yen H.-C, Wall JD: Analysing the metabolic capabilities of Desulfovibrio species through genetic manipulation. Biotechnol Genet Eng Rev 2006, 23:157-174.

34. Butler JE, Glaven RH, Esteve-Núñez A, Núñez C, Shelobolina ES, Bond DR, Lovley DR: Genetic characterization of a single bifunctional enzyme for fumarate reduction and succinate oxidation in Geobacter sulfurreducens and engineering of fumarate reduction in Geobacter metallireducens. J Bacterio/ 2006, 188:450-455.

35. Kim BC, Postier BL, Didonato RJ, Chaudhuri SK, Nevin KP, Lovley DR: Insights into genes involved in electricity generation in Geobacter sulfurreducens via whole genome microarray analysis of the OmcFdeficient mutant. Bioelectrochemistry 2008, 73:70-75. Erratum in: Bioelectrochemistry 2008, 74:222

36. Keller KL, Bender KS, Wall JD: Development of a markerless genetic exchange system in Desulfovibrio vulgaris Hildenborough and its use 
in generating a strain with increased transformation efficiency. Appl Environ Microbiol 2009, 74:7682-7691.

37. Guedon E, Payot S, Desvaux M, Petitdemange H: Carbon and electron flow in Clostridium cellulolyticum grown in chemostat culture on synthetic medium. J Bacteriol 1999, 181:3262-3269.

38. Desvaux M: Unravelling carbon metabolism in anaerobic cellulolytic bacteria. Biotechnol Prog 2006, 22:1229-38.

39. Villanueva L, Haveman SA, Summers ZM, Lovley DR: Quantification of Desulfovibrio vulgaris dissimilatory sulfite reductase gene expression during electron donor- and electron acceptor-limited growth. Appl Environ Microbiol 2008, 74:5850-5853.

40. Walker CB, He Z, Yang ZK, Ringbauer JA Jr, He Q, Zhou J, Voordouw G, Wall JD, Arkin AP, Hazen TC, Stolyar S, Stahl DA: The electron transfer system of syntrophically grown Desulfovibrio vulgaris. J Bacterio/ 2009, 191:5793-5801.

41. Esteve-Núñez A, Núñez C, Lovley DR: Preferential reduction of Felll over fumarate by Geobacter sulfurreducens. J Bacterio/ 2004, 186:2897-2899.

42. Esteve-Núnez A, Rothermich M, Sharma M, Lovley D: Growth of Geobacter sulfurreducens under nutrient-limiting conditions in continuous culture. Environ Microbiol 2005, 7:641-648.

43. Cardenas E, Wu WM, Leigh MB, Carley J, Carroll S, Gentry T, Luo J, Watson D, Gu B, Ginder-Vogel M, Kitanidis PK, Jardine PM, Zhou J, Criddle CS, Marsh TL, Tiedje JM: Microbial communities in contaminated sediments, associated with bioremediation of uranium to submicromolar levels. Appl Environ Microbiol 2008, 74:3718-3729.

44. Wilkins MJ, Verberkmoes NC, Williams KH, Callister SJ, Mouser PJ, Elifantz H, N'guessan AL, Thomas BC, Nicora CD, Shah MB, Abraham P, Lipton MS, Lovley DR, Hettich RL, Long PE, Banfield JF: Proteogenomic monitoring of Geobacter physiology during stimulated uranium bioremediation. Appl Environ Microbiol 2009, 75:6591-6599.

45. Howarth RW: A rapid and precise method for determining sulfate in seawater, estuarine waters, and sediment pore waters. Limnol Oceanogr 1978, 23:1066-1069.

46. Desvaux M, Guedon E, Petitdemange H: Carbon flux distribution and kinetics of cellulose fermentation in steady-state continuous cultures of Clostridium cellulolyticum on a chemically defined medium. $J$ Bacteriol 2001, 183:119-30

47. Zaunmüller T, Kelly DJ, Glöckner FO, Unden G: Succinate dehydrogenase functioning by a reverse redox loop mechanism and fumarate reductase in sulphate-reducing bacteria. Microbiol 2006, 152:2443-53.

48. Harris RF, Adams SS: Determination of the carbon-bound electron composition of microbial cells and metabolites by dichromate oxidation. Appl Environ Microbiol 1979, 37:237-243.

49. Postgate JR, Kent HM, Robson RL, Chesshyre JA: The genomes of Desulfovibrio gigas and D. vulgaris. J Gen Microbiol 1984, 130:1597-1601.

50. Caccavo F Jr, Lonergan DJ, Lovley DR, Davis M, Stolz JF, Mclnerney MJ: Geobacter sulfurreducens sp. nov., a hydrogen- and acetate-oxidizing dissimilatory metal-reducing microorganism. Appl Environ Microbiol 1994, 60:3752-3759.

51. Kraemer JT, Bagley DM: Supersaturation of dissolved $\mathrm{H}_{2}$ and $\mathrm{CO}_{2}$ during fermentative hydrogen production with $\mathrm{N}_{2}$ sparging. Biotechnol Lett 2006, 28:1485-1491

52. Brock TD, ML Brock, TL Bott, Edwards MR: Microbial life at $90^{\circ} \mathrm{C}$ : the Sulfur Bacteria of Boulder Spring. J Bacterio/ 1971, 107:303-314.

53. Hicks RE, Amann RI, Stahl DA: Dual staining of natural bacterioplankton with 4,6-diamidino-2-phenylindole and fluorescent oligonucleotide probes targeting kingdom-level $16 \mathrm{~S}$ rRNA sequences. Appl Environ Microbiol 1992, 58:2158-2163.

doi: 10.1186/1471-2180-10-149

Cite this article as: Miller et al., Establishment and metabolic analysis of a model microbial community for understanding trophic and electron accepting interactions of subsurface anaerobic environments BMC Microbiology 2010, 10:149

\section{Submit your next manuscript to BioMed Central} and take full advantage of:

- Convenient online submission

- Thorough peer review

- No space constraints or color figure charges

- Immediate publication on acceptance

- Inclusion in PubMed, CAS, Scopus and Google Scholar

- Research which is freely available for redistribution 